\title{
A Study of the Advaita Vedāntic Critique of Anyathākhyātivāda
}

\author{
Trisha Paul \\ Department of Philosophy, University of Calcutta, Kolkata, India
}

Email address:

trishapaul517@gmail.com

\section{To cite this article:}

Trisha Paul. A Study of the Advaita Vedāntic Critique of Anyathākhyātivāda. International Journal of Philosophy.

Vol. 9, No. 1, 2021, pp. 60-65. doi: 10.11648/j.ijp.20210901.15

Received: January 29, 2021; Accepted: February 26, 2021; Published: March 10, 2021

\begin{abstract}
We usually discuss the question of determining the logical meaning of error and that of finding out the psychological conditions under which error is made possible. It is important to consider the general implications of those judgments regarding the ontological status of an illusory object. Unlike their Western counterpart, the investigation of an erroneous cognition has drawn the special attention of ancient philosophers of India. As a result, in Indian philosophy there are different theories of error which are propounded by different philosophers in accordance with the ontological schemes of their schools of philosophy. This paper is an attempt to critically discuss the Naiyāyikas' view of error called Anyathākhyātivāda with special attention to the Advaita Vedāntic critique of it. It is interesting to analyze different new arguments that have been developed by the later philosophers of these schools. The investigation of an erroneous cognition by the philosophers of Advaita Vedānta has been continuing from Śākarācarya to the modern Indian philosophers who refute the Nyāya position with new arguments. In what follows we propose to discuss critically some of these arguments.
\end{abstract}

Keywords: Single Complex Unitary Cognition, Extra-ordinary Perception, Ordinary Perception, Locus

\section{Introductory Remarks}

The Nyāya philosophy is primarily concerned with the conditions of a valid cognition (pramā) and the causal means of such cognition (pramāna). In Sanskrit, it is called jñ̄ana which roughly corresponds to 'knowledge' in English. According to the Nyāya philosophy, knowledge is the manifestation of object. The object of knowledge arises from some specific conditions which are known as jūānakarana (the organs of knowledge). When the knowledge is true, these specific conditions are called pramanna (the instrument of a valid knowledge). On the contrary, the false knowledge (apramā) does not arise from pramāna (the instrument of a valid knowledge). Thus, no knowledge can be true or false on the basis of its own account. A piece of knowledge is true when it corresponds to the real object, it is called a valid cognition (pramā). If not, it is called an invalid cognition $($ apramā $)$. It means that according to the Naiyāyikas, the validation of knowledge (prāmānya) depends on some certain specific conditions (kārana). The basic features of a valid knowledge (pramā) which are accepted by almost all schools of Indian philosophy, is non-contradictoriness (anadhigatābādhita). [1] A valid cognition (pramā) cannot be refuted by any subsequent cognition. But in the case of an invalid cognition (apramā), it is corrected by the subsequent cognition.

On the other hand, the Advaita Vedāntīns recognize three ultimate categories --- being (sat), non-being (asat) and falsity (mithyā). Being (sat) cannot be denied any time or anywhere, but it is present everywhere. On the other hand, non-being (asat) does not exist but it is sublated logically. Falsity (mithya $)$ is different from both being (sat) and nonbeing (asat). It is different from being (sat), because it is sublated later, when we come to know the ultimate reality. It is also distinct from non-being (asat), because it (non-being) has no locus, like sky-flower. But falsity (mithya) is presented in a locus. It can be felt and denied also. That is why, it is also called felt reality (vyāvahārika satvā) which is sublated by the supreme reality. [2] According to the Advaitīns, the world is a perceived fact, which can feel like a snake. But when the reason helps us to accept the real truth then we cancel the false appearance (felt reality or vyāvahārika satvā, which is also known as anirvacanīya) by the superior merit (pāramārthika satvā). [3] 
So, every philosopher holds the view that truth should be non-erring, non-dubious and novel (anadhigatābādhita). But when we perceive a snake in a rope then it is not a valid cognition (pramā). Because when we perceive the rope properly without any barrier then the cognition of a snakerope (viparyaya jñāna) is sublated by the real cognition of snake. So, it follows that the valid cognition (pramā) cannot be neglected. [4]

\section{Meaning of Anyathākhyātivāda}

Anyathākhyāti has been explained as the doctrine, according to which something, say ' $x$ ' is previously known (adhigata) in some other contexts, say ' $\mathrm{y}$ ' for which that something ' $\mathrm{x}$ ' is mistakenly cognized to the present object. In this manner Anyathākhyāti is understood in the terms of anyatra (elsewhere) and anyakāla (else when). But this, by no means, seems to follow from the meaning of the term anyatha (elsewise). Error is defined in the terms of 'atasmin tad iti jñ̄anam' [5] which thereby means of cognition (in the sense of judging) something as what it is not. It is cognizing which is found to be defective and not the real object. [6] The object remains what it is. That is of no concern for a logical analysis of an erroneous cognition (viparyaya jñanna). So, to search for a peculiar kind of object for an erroneous cognition (viparyaya jūanna) is simply to miss the point.

\section{Error is a Single Complex Unitary Cognition}

Firstly, we may have the contact of sense with something which is present before us. Owing to some defects, the sense organ cognizes such general features of the thing; as its brightness, whiteness etc. But sometimes our sense organ may fail to discern its peculiar and distinctive feature. Here, the common features (samāna-dharma) are being associated with some other thing (silver). When we recall the memoryimage of the peculiar properties of that other thing through such recollection there is a sort of extra-ordinary contact (jñāna-lakșaṇa sannikarșa) between sense organ and that other thing (silver). Hence, this is an actual perception of the silver in the illusory case. The perceived silver is then referred to the locus (idam or this) which is not actually present here, which was present before elsewhere and now it (silver) is perceived by sense organ through the jñannalakșaṇa sannikarșa (extra-ordinary contact). Hence, in the case of an illusory perception (bhrama), there is perception of both 'this' and the 'silver', although in different ways. [7] The cognition of 'this' and the cognition of the 'snake' are both real. According to the Naiyāyikas, error (viparyaya) is a combination of two knowledges where one consists in the given content which is actually a positive single complex unitary cognition. Though, the snake is perceived by the extra-ordinary perception (jñāna-lakșaṇa sannikarșa) and 'this' is perceived by the ordinary perception (laukika sannikarșa). Here, the perception of the snake is included with 'this'. That is why, it is a combination of two cognitions where one consists with another and we mischaracterize it with another object.

Hence, the error does not lie in the presentation which is concerned with the perception but in the determination of one presentation by another given through association and memory (jātyasamskārāt). Therefore, this determination is a result of a judgment of the object, as something other than what it is. The Nyāya theory of error is called Anyathākhyāti or Viparītakhyāti. According to it, an erroneous cognition (viparyaya jūanna) is presentational in character and has some basis in facts. But these facts become misplaced and misrelated, when error becomes a false apprehension of the real. [8] This means that error is a case of misjudgment. The presented object is perceived elsewise and the represented object exists elsewhere. The shell and the silver are both separately real (sat), only their synthesis as 'shell-silver' is unreal (asat). The Nyāya-Vaiśeșika philosophers recognize the objective elements in error. Error is due to a wrong synthesis of the presented objects.

\subsection{Justification for the Possibility of Invalid Knowledge}

According to the Nyāya philosophers, when we perceive a snake in a rope, we perceive 'this' by our ordinary senseobject contact (laukika sannikarșa). On the flip hand, the snake is perceived by an extra-ordinary contact (jñannalakșana sannikarșa). As all the philosophers have accepted that the snake is the object of knowledge (prameya) in the case of a snake-rope illusion, we cannot deny it as an instance of knowledge. But it is non-contradictory with its own object. On the other hand, in the snake-rope illusion we cannot also deny that we are perceiving the rope and gaining the knowledge of a snake. Now it stands as such that when the rope lies in front of the perceiver, it is quite natural that the perceiver must have perceived the rope, not the snake. But here, in the snake-rope illusion, the rope is qualified by snake-hood and the perceiver perceives the snake, not the rope. It happens because of some common features (samānadharma) of the two objects, such as their characteristic curvature in their appearance, etc. The perceiver perceived the jungle snake elsewhere. In the snake-rope illusion, when the perceiver perceives the rope, he mischaracterizes it with the jungle-snake. Due to some defects, the rope seems to be a snake.

It is to be mentioned that although the perceiver perceives the snake, but here, the rope lies in front of him, which he perceives through his ordinary sense contact (laukika sannikarșa) without its special attribute (viśeșa-dharma). On the other hand, the snake is also not present here. Then how could it be possible that the perceiver gains the knowledge of a snake 'here and now' which is already absent here? It is certain that when he cognizes the rope as a snake, he reacts immediately without any doubt (samiśaya). So, it is followed that the snake is perceived by the perceiver without any doubt (samśaya). It is a basic difference between samiśaya and viparyaya (dubious cognition and erroneous cognition).

According to the Naiyāyikas, error arises when we mischaracterize one thing with another. Firstly, something is given to the perceiver, but he could not differentiate it from 
the other things by its special attribute (viśesa-dharma). Actually, he fails to differentiate its peculiar and distinctive features from the others. Secondly, the general features (samana-dharma) of two objects (like. curvature) also help to recall the memory-image of a snake which he perceived in the jungle. Through such recollection (smrti-jñāna), there is a sort of extra-ordinary contact (jñāna-lakșaṇa sannikarșa) between the immediate visual sense of the rope and the jungle snake. As the perceiver perceives the real snake by the extra-ordinary perception (jñanna-lakșaṇa sannikarșa), the cognition of a snake is also real.

\subsection{Non-perceptual Cognition}

Different theories of error are concerned with the nature of the object. In the case of an erroneous cognition (viparyaya jūana), the object is erroneously cognized. When we look at a shell of the mother pearl which is known as a nacre (śukti), we may perceive it as it is. This is a case of a valid cognition (pramā). But sometimes it does not happen. Its silver-white shine may mislead us to take it to be a piece of a silver (rajat). This type of psychological terminology is known as illusion (bhrama). It is to be contrasted with hallucination. In the case of a hallucination, we perceive a thing without there being any object. A false perception is also called bhrama in Sanskrit. It may be divided into two classes. [9] In one case there is an objective basis, but the cognition is false. Such as, the nacre (śukti) is mistakenly perceived as a silver (rajat). It is called salambana bhrama in Sanskrit. On the other hand, there is no objective basis. It is called hallucination, nirālambana bhrama in Sanskrit. Error (viparyaya) refers to the first kind of false perception. The classical Indian theories of error mostly deal with the issues which are related to the perceptual error. Perception is a causal instrument (pramāna) of knowing. The Indian philosophers are also aware of the possibility of erroneous beliefs which are also arising out of non-perceptual causes. The error arises in our cognitive part. When we come to know the correct one, we sublate the consequent part which is wrongly connected with our psychosis.

\section{Advaita Vedāntic Critique of Anyathäkhyātivāda}

The Śan்karite Advaita Vedānta philosophers have pointed out that according to the Nyāya philosophy, the perceiver perceives 'this' in the form of a real snake. When we perceive the snake in 'this', the snake is not apprehended as a jungle snake but as a 'this snake', - the snake is not lying infront of the perceiver, but it is perceived in 'this' as 'this snake.' Now the question is, how could it be possible that the jungle-snake which is perceived by an extra-ordinary contact (jñana-lakșaṇa sannikarșa) is magically translated as a 'this snake?' Here, the elsewhere jungle-snake has mysteriously attached itself with 'this' which is appearing before to the perceiver.

According to the Nyāya philosophers, in the case of an illusory perception and the fragrance of sandalwood both are possible through the jũanna-lakșaṇa sannikarșa (extraordinary contact). The fragrance is perceived by the visual contact instead of the nasal contact, as the perceiver had a past nasal experience of that fragrance. Now, when he perceives the sandal wood by his ordinary visual sense (laukika sannikarșa), it revives the past experience of the fragrance. This experience works as a connecting link between the visual sense contact and the fragrance although the object is, so far, away from the perceiver. Here, the Sańkarite Advaita philosophers have pointed out that we are conscious of perceiving the sandal wood, not its fragrance. Fragrance is reminded by our past experiences (smrti-jñanna).

If the Nyāya accepts that the fragrance of sandalwood is perceived by an extra-ordinary sense (jñāna-lakșana sannikarșa), it will make inference (anumāna) psychologically impossible. Inference (anumāna) is based on an invariable concomitance-relation between the hetu (prabans / sign / indicator reason) and the sādhya (prabandum / the inferable object). When we perceive smoke on a hill, we revive our past experience of invariable concomitance-relation between the hetu (prabans / sign / indicator reason) and the sädhya (prabandum / the inferable object). The fire is the cause of the smoke. If there is present any smoke, the fire must be present too. At first, we perceive the smoke on the hill and then we revive our past experience and this experience (samiskära) works as a connecting link between the fire and the hill, although the fire is not perceived. Concomitance-relation between the hetu (prabans / sign / indicator reason) and the sädhya (prabandum / the inferable object) introduce the fire on the hill. The middle term (hetu) is always related to the major term (sädhya). It is the result of our previous experience of their relation with each other. After that, this memory-judgment connects the fire with the hill. We perceive the fire on the hill by our extra-ordinary perception (jñāna-lakșaṇa sannikarșa). This is called parāmarśa-jñāna (knowledge arises immediately due to psychological ground).

Now, the Śankarite philosophers argue that if we gain the knowledge of the fire on the hill by the extra-ordinary sense perception (jñanna-lakșaṇa sannikarșa) then why are we inferring the fire on the hill? We have a complicated perception of the 'fire' on the hill instead of an inference (anumāna) of it. The appearance of perception (pratyaksa) will make the appearance of inference (anumāna) impossible. So, if the Nyāya philosophers accept the jñāna-lakșana sannikarșa (extra-ordinary contact), they cannot give a satisfactory answer about the inference (anumāna).

Here, in response, the Nyāya philosophers argue that in the case of an ordinary perception (laukika sannikarșa) and an inference (anumāna), an ordinary perception (laukika sannikarșa) is more effective than an inference (anumāna). However, in the case of an extra-ordinary perception (jñānalakșaṇa sannikarșa) and an inference (anumāna), an inference (anumāna) is more effective than an extra-ordinary perception (jñāna-lakșaṇa sannikarșa). Although, this Nyāya view is not a satisfactory answer to the objection raised by the Vedāntic philosophers. They argue that in the case of a doubt as either a post or a man, the question arises like, 
"What is it? Is it a post or is it a man?" [10] In the case of a doubt, when we characterize it (a post) as a man, the question arises like, how can we get to know that this is a man? Is it known through the perception (pratyakșa) or by the inference (anumāna)? The lay man would answer: "it is a type of inference (anumāna)." However, according to the Nyāya philosophers, it is not an inference (anumāna) but a perception (pratyaksa). Now, a question will arise again-which type of perception (pratyaksa) is it? It could not be an ordinary perception (laukika pratyaksa) because, in the case of an ordinary perception (laukika pratyaksa) the relation between the object and the sense organ, is the necessary condition. However, in the case of a doubt, the object of knowledge (man with its special attribute) is not present infront of the perceiver. The perceiver perceives the object of knowledge (man with its special attribute) through the jñanalakșana sannikarșa and thus it is an extra-ordinary perception (alaukika pratyaksa), not an inference (anumāna). By that explanation we can conclude that also in the case of the dubious cognition (samśaya), an extra-ordinary perception (alaukika pratyaksa) is more effective than an inference (anumāna) which is a contradiction to the Naiyāyikas' argument mentioned above.

The Vedāntic philosophers here argue that if the Nyāya philosophers admit the jñanna-lakṣaṇa sannikarșa (extraordinary contact), they cannot accept the inference (anumāna) as a pramāna (the instrument of a valid knowledge). Now, if they deny the jũāna-lakșaṇa sannikarșa (extra-ordinary contact), then how will they give a satisfactory answer about an illusory perception and the perception of sandal wood?

In the case of a snake-rope illusion, if the Nyāya admits that the snake is perceived by the jñanna-lakșana sannikarșa (extra-ordinary contact), another problem will arise. When we perceive sandal wood by our sense perception (laukika sannikarșa), we have the knowledge of the fragrance of sandal and the form of anuvyavasāya (cognition of cognition or self-consciousness) is 'I know that this is the fragrance of sandal wood'. But we do not say that 'I know the fragrance of sandal wood through my sense organ'. As in the case of an illusory perception (viparyaya jñ̄ana), we know the snake through the jñanna-lakșaṇa sannikarșa (extra-ordinary contact) and the form of anuvyavasāya (cognition of cognition or self-consciousness) is ' $I$ know that this is a snake'. We do not say that 'I know the snake through my sense organ'. But everyone accepts that we know the snake in a rope through our sense perception. So, it can be said that whatsoever the Nyāya gives an explanation about the jñannalakșana sannikarșa (extra-ordinary contact), it is not a satisfactory answer at all.

The Nyāya claims that due to some similarities with a rope when the perceiver perceives the snake in a rope which is lying in-front of him, the cognition of a real snake arises through samskāra (previous experience) which is perceived before. The Advaitīns argue that if the Nyāya accepts it without any sense contact due to some similarities with the lying object -- 'this' is perceived as elsewhere snake,-- then they (Naiyāyikas) have to accept smrti (memory) as pratyakșa (perception). Because smṛti or memory arises through only samiskâra (previous experience), [11] that is to say, without any sense contact. Thus, the Naiyāyika cannot establish in the case of an illusory perception, the cognition of a snake arises through samskāra (previous experience) and it is perceived through the jũanna-lakșaṇa sannikarșa (extra-ordinary contact). If they (Naiyāyikas) accept it, then they have no justification about memory or smrti.

The Naiyāyikas also admit that the elsewhere jungle-snake appears in the illusory perception as identified with the yonder object. But the question is: when we perceive the snake in a rope, does it mean that the snake is in remote distance? The answer is in the negative. It shows only 'this' as a snake, but it does not conclude that the perceived snake as a remote distant. So, the Nyāya who claims the junglesnake which is perceived in a rope, the distance of the existent snake is not proved by the any cognition. Because the elsewhere snake where it is perceived, it does not exist in 'this' locus.

The Nyāya suggests that if the distant snake does not assume, the correction of the snake will be meaningless. Correction means when we confirm the snake as a rope then this subsequent cognition (true cognition of a rope) negates the false appearance of the snake. But the correction does not prove that where the snake is perceived in the locus or 'this', this perceived object is distant. The snake is perceived in a rope, where it does not exist actually. That is why, the Naiyāyikas have to accept that the snake must exist in somewhere. Because if the Nyāya does not accept the remote snake then the cognition of the object is accepted as nonexistent. If it is so then how will we consider that the cognition always refers to its own object? [12]

The Vedāntīns argue that the correction will be meaningless, if the silver does not cognize in the same place, where it is perceived. But if we accept it as a piece of apparent silver (rajat) which is perceived in the nacre (śukti) then it can be solved. When the error is vanished then we come to realize the nacre (śukti) with its own attributes (suktitva) and recognize it as "this is not a silver (rajat)." The silver is a false appearance. It covers the actual reality that is nacre $(\dot{s} u k t i)$. When the false appearance $(m \bar{a} y \bar{a})$ disappears then the actual reality manifests itself. [13]

When we misjudge something with another, due to some similarities, an error arises. After correcting it by the valid cognition, we become able to understand that we were wrong. Hence, if we perceive the distant object by the jñanalakșaṇa sannikarșa (extra-ordinary contact), it cannot be proved by the anuvyavasāya (cognition of cognition or selfconsciousness).

According to the Naiyāyikas, the relation between snakeness and the snake is samavāya (inherence). But what is the relation between the snake and the rope? Does there any relation exist at all? According to the Naiyāyikas, error arises through a single complex unitary experience. When we claim 'this' as a snake, it is divided like the snake, 'this' and their relation which all are sat (existents). According to them (Naiyāyikas), 'this' and the snake both are sat (real) and they 
are also perceived. But according to the Vedāntīns, the false elements in error consist in a false relation. The relation between these contents is false, because the contents are related wrongly. In this instance 'this is a snake', our cognition is a false cognition. In the case of a true cognition, snake-hood inherits in a snake. The relation between the snake and snake-hood is samavayya (inherence). But here, the relation between 'this' and the 'snake' is false. So, in the case of an erroneous cognition (viparyaya jūāna), no relation resides in this false content. Now the question arises, how can a recollection of an elsewhere snake serve as a connecting link between 'this' and the 'snake'?

According to the Śankkarite philosophers, "this is a snake," is an indivisible unit. But the Naiyāyikas falsely split it into a 'this', 'a snake' and 'a relation between the two'. According to the Advaita Vedātīns, the error is neither sat (real) nor asat (unreal). Why is it not sat (real)? Because 'sat' (real) cannot be refuted by some other. Why is it not asat (unreal)? Because it is perceived by the sense organ. Sky-flower, child of a barren-mother etc. they do not exist anywhere. They are not perceived through the sense organs. But we can perceive a snake in a rope. That is why, it is not an absolute 'nought'. So, error is neither sat nor asat (neither real nor unreal). Now, the question is: if it is neither sat (real) nor asat (unreal), then how can it be described? According to the Advaitīns, error is anirvacanīya (indescribable). [14] When the cognizer cognizes the real rope, he immediately rejects the 'here and now' snake which is perceived earlier falsely. For the Advaita Vedatinns, the snake may be present somewhere, which is always connected with the reality. We can deny only which is falsely perceived as a snake. When we cognize the real object, we can deny the snake absolutely and the rejection is an absolute rejection.

\section{Some More Analysis on Naiyāyikas' View}

The theory of Anyathākhyāti of the Nyāya philosophy is founded in the writings of Udayanācārya, Jayanta Bhatța, Srīdharācārya and such other scholars, including Vācaspati Miśra. Vācaspati in his Nyāya-Vārttika-Tātparyațīkā asserts that similarity is the root of all kinds of erroneous cognitions (viparyaya jñ̄nna). In the erroneous cognition (viparyaya jñana) like the 'shell-silver' case, there are certainly some sort of similarities, which play its role in bringing about superimposition which bring in its wake an invalid judgment. Jayanta Bhatța points out that an invalid cognition is a single unitary cognition. His position may be best explained by a reference to Jayanta's and Śrīdhara's analysis of the phenomenon of acquired perception. Srīdhara holds that the visual perception of 'the fragrance of sandal (surabicandanam) is generated by the visual organ which apprehends the substantive sandal only in collaboration with the previous olfactory perception of fragrance. [15] On this point, Jayanta Bhatța says that the fragrance of sandal (surabi-candanam) is not perceived by the visual organ, but by the mind. [16] According to him, this is a new type of a synthetic unity of apperception. Hence, it seems that according to Jayanta Bhatta, an error is the result of a synthetic unity of apperception of the presentative elements and the representative elements.

It is doubtlessly a merit on the part of the Naiyāyikas, who are the great advocates of Nyāya or valid reasoning to emphasize the important point 'anyathā' in Sanskrit, it means in somewhere else, it can be regarded as the definition that the silver characteristic is not completely rejected as obsolete. Only the attribution of the silver-characteristic over the present referent is denied. However, the silvercharacteristic as being applied to a different referent (silver), is not denied. The silver-characteristic has an application in a different context. When the wrong judgment is corrected, it does not mean that the phrase 'being silver' is non-significant or it has no application. Error is a false judgment of the real through the attribution of such characters as are excluded by it (viparīta-dharmādhyāropena). [17]

\section{Concluding Remarks}

From what has been discussed so far, it appears that the Indian philosophers largely believe that all cognitions are presumably to be valid and our normal life runs smoothly on the account of this belief. A need for explanation is felt only when the knowledge fails to be valid. A cognition or belief is not known as an erroneous cognition (viparyaya jñanna) unless it is corrected (bādhita) by some subsequent cognition. [18] When we perceive the silver in a shell then it is corrected by some subsequent cognition. like "this is not a silver"-- "nedam rajatam." The false apprehension takes its character as false, from the nature of the content apprehended. Correction rejects the object of knowledge, which is perceived erringly. A mistake remains a mistake unless we correct it. When the snake is perceived in the rope mistakenly, the perceiver perceives it (rope) as a real snake. After the true cognition of a rope and the negation of cognition of the snake, the perceiver perceives the actual content and he denies the false cognition (cognition of a snake). There is a logic behind it:

Either it is a snake or it is a rope: $(\mathrm{P} \vee \mathrm{Q})$

It is not a snake: $\sim \mathrm{P}$

Therefore, it is a rope: Q. (by Disjunctive syllogism).

Both the rope and the snake--- these two cannot exist in the same locus. The negation of a snake concludes the existence of a rope.

For that very reason, it could not be possible that in the same locus both the snake and the rope exist. It is contradictory to our empirical thought. Also, it is true that the same object cannot be perceived by anyone in the same place differently. One perceives the snake and the other perceives the rope, because whatsoever we know in our empirical world, we know it in space and time. And if we admit that, then we have to accept that when we perceive a snake in a rope, it must exist in space and time. Then how could it be possible that in the same locus we do realize that we were wrong before we perceived the different object (snake) in its original manner (like rope)?

In that case, the Advaita Vedāntīns' argument is more 
satisfactory. In our empirical world, whatsoever we know, we know it in space and time. But this empirical world is not real according to the Advaitīn philosophers. Māyā covers the actual reality (Brahman) by its power and it creates a false appearance of Brahman which is known to us as jagat (world). But when we come to realize the actual reality then we can understand that the world is a false appearance of Brahman, which is called mithya (false appearance), and this empirical world (vyāvahārika jagat) is sublated by the superior merit (pāramārthika satvā). So, in our empirical world when we perceive a snake in a rope, in a specific space and time, the error arises. However, according to the Advaita Vedāntīns, when we come to realize the actual reality then the empirical world is totally vanished which exists in a specific space and time. [19]

When we are in error, we cannot realize it but when we are aware of it, then it goes away. We cannot find it. What seems to be convincing is that the different conflicting theories of illusion grew up as integral parts of different philosophical systems of Indian philosophy with different ontological positions. [20]

\section{References}

[1] Dhirendra Mohan Datta: The Six Ways of Knowing, George Allen \& Unwin Ltd., London, 1932, p. 20.

[2] Anil Kumar Ray Chaudhuri: Self and Falsity in Advaita Vedānta, Progressive Publishers, 37, College Street, Calcutta, 1955, pp. 118-119.

[3] Karl Potter: Presuppositions of India's Philosophies, PrenticeHall International, INC, London, 1963, p. 221.

[4] Śrī Śańkarācārya: Aparokșānubhūti, Eng. Trans. Swāmī Vimuktānanda, Advaita Ashrama, 5, Delhi Entally Road, Kolkata, 2020, p. 57.

[5] Uddyotkara: Nyāya-Vārttika, Bibliotheca Indica, Calcutta, 1907, p. 26.

[6] Susil Kumar Maitra: Fundamental Questions of Indian Metaphysics and Logic, First Edition, Published by the author, 48G, Anath Nath Dev Lane, University of Calcutta, Calcutta, 1956, p. 130.
[7] Satischandra Chatterjee: The Nyāya Theory of Knowledge, University of Calcutta, Calcutta, 1950, p. 65.

[8] Arindam Chakrabarti: Mananera Madhu, (in Bengali), Gānacila, First Edition, 2008, pp. 217-234.

[9] Nani Lal Sen: A Critique of The Theories of Viparyaya, Rabindra Bharati University, Calcutta, 1965, p. i.

[10] Ashutosh Bhattacharyya Shastri: Vedānta Darshan Advaitavāda, (in Bengali), Vol. 2, University of Calcutta, Calcutta, 1949, pp. 422-425.

[11] Sadānanda Yogīndra: Vedāntasāra, Bengali Trans. Loknath Chakraborty, West Bengal State Book Board, 2011, p. 275.

[12] Anil Kumar Ray Chaudhuri: The Doctrine of Māyā, Dasgupta \& Co., Calcutta, 1950, pp. 26-28.

[13] Dharmarājāadhvarīndra: Vedānta-Paribhāṣā, Eng. Trans. Swāmī Mādhavānanda, Advaita Ashrama, 5, Delhi Entally Road, Kolkata, 2019, pp. 39-41.

[14] Chandradaya Bhattacharyya: Advaita Vedānte Ajñāna, (in Bengali), Sanskrit College, 1, Bankim Chatterjee Street, Calcutta, 1994, pp. 6-10.

[15] Mridula Bhattacharyya: Khyātivāder Digdarśan, (in Bengali), First Edition, Maha Bodhi Book Agency, College Square, Kolkata, 2015, pp. 21-27.

[16] Jayanta Bhaț̣a: Nyāya Mañjarī, Vizianagaram Sanskrit Series, Benaras, 1895, (Ed.) Suryanarayan Sukla, Chowkhamba, Benaras, 1936, p. 36.

[17] Bijayananda Kar: The Theories of Error in Indian Philosophy, Ajanta Publication, Delhi, 1978, p. 63.

[18] Rupa Bandyopadhyay: Indian Theories of Illusion, First Edition, Maha Bodhi Book Agency, College Square, Kolkata, 2020, p. 1.

[19] Rasvihary Das: Kanter Darshan, (in Bengali), Fifth Edition, West Bengal State Book Board, 2011, p. 37.

[20] Stephen H. Phillips and N. S. Rāmānuja Tattvacharya: "From Gangeśa's Tattvacintāmani: Discourse on Perceptual Presentation of Something as Other than What It Is Anyatha $\bar{a}$ khyāti-vāda", Journal of Indian Philosophy, Vol. 28, 2000 pp. 567-650. 